\title{
Protective Effects of Oral Sirolimus Therapy against ESWL-induced Kidney Tissue Damage in Rats
}

\author{
Ratlarda ESWL Sonrası Oluşan Böbrek Doku Hasarında Oral Sirolimus Tedavisinin Etkisi
}

\author{
(1) Mehmet Necmettin Mercimek1, (1) Yakup Bostancı2 , (1) Ender Özden2, (1) Şaban Sarıkaya² \\ 1Samsun Liv Hospital, Clinic of Urology, Samsun, Turkiye \\ 2Ondokuz Mayıs University, Department of Urology, Samsun, Turkiye
}

\begin{abstract}
What's known on the subject? and What does the study add?
To date, there are no studies showing the long-term effects of extracorporeal shock wave lithotripsy (ESWL) on the kidney in detail. In experimental studies, only dose-dependent renal fibrosis formation has been demonstrated in dogs and rabbits by different researchers. However, it is unclear whether or not to reduce ESWL-induced tissue damage. In this study, it was determined that sirolimus decreased the histopathological changes related to ESWL on the kidney in long term. To conclude, we think that sirolimus may be beneficial in order to protect the existing renal functions and to decrease the tissue damage in kidney tissue after.
\end{abstract}

\begin{abstract}
Objective: In the present study, we aimed to investigate the short- and long-term protective effects of oral sirolimus therapy on extracorporeal shock wave lithotripsy (ESWL)-induced kidney tissue damage in an experimental rat model.

Materials and Methods: Twenty-four male Spraque-Dawley rats were used in the study. A total of 1000 shock waves (SWs) were applied to the left kidney of all rats at $15 \mathrm{kV}, 60 \mathrm{SW} / \mathrm{min}$. Two main groups, ESWL (group 1) and ESWL sirolimus (group 2), were formed. Each group was divided into two subgroups as early (E) and late (L). Left nephrectomy was performed on the $15^{\text {th }}$ day in $E$ groups and on the $60^{\text {th }}$ day in $L$ groups. Tubular injury, interstitial changes, as well as scar formation, were scored semi-quantitatively for at least 10 cortical fields in each sample. An average score was calculated for each subject. Independent samples t-test was used for statistical analysis. The statistical significance was accepted as $p<0.05$.

Results: The mean histopathological score was $0.08 \pm 0.94$ and $0.15 \pm 0.65(p=0.332)$ in group $1 \mathrm{E}$ and $2 \mathrm{E}$ and it was $0.27 \pm 0.17$ in group $1 \mathrm{~L}$ and $0.05 \pm 0.06$ in group $2 \mathrm{~L}$, respectively $(p<0.05)$. When group $1 \mathrm{E}$ and group $1 \mathrm{~L}$ were compared, the mean score was $0.08 \pm 0.94$ and $0.27 \pm 0.17$, respectively $(p<0.05)$. Furthermore, there was also a statistically significant difference in mean histopathological score between group $2 \mathrm{E}$ and group $2 \mathrm{~L}$. The mean score was $0.15 \pm 0.65$ vs $0.05 \pm 0.06(p<0.05)$.

Conclusion: Depending on SW power and frequency, ESWL may cause significant histopathological changes in rat kidneys in the chronic period. In this experimental study, it has been thought that sirolimus treatment may have a tissue protective effect against long-term renal tissue damage.

Keywords: Histopathologic changes, Kidney, ESWL, Sirolimus
\end{abstract}

Öz

Amaç: Bu çalışmada, deneysel rat modelinde oral sirolimus tedavisinin ekstrakorporeal şok dalgası tedavisi (ESWL) sonrası oluşabilecek böbrek dokusu hasarı üzerine kısa ve uzun dönemde koruyucu etkilerini araştırmayı amaçladık.

Gereç ve Yöntem: Bu çalışmada 24 erkek Spraque-Dawley rat kullanıldı. Tüm ratların sol böbreğine 15 kV, 60 SW/dk'da toplam 1000 şok dalgası uyguladı. İki ana grup, ESWL (grup 1) ve ESWL sirolimus (grup 2) oluşturuldu. Her grup erken (E) ve geç (L) olmak üzere iki alt gruba ayrıldı. Sol nefrektomi 15. günde E gruplara, 60. günde L gruplara yapıldı. Tübüler hasar, interstisyel değişiklikler ve skar oluşumu, her denekte en az 10 kortikal alanı için yarı kantitatif olarak skorlandı. Her denek için ortalama bir puan hesaplandı. İstatistiksel analiz için bağımsız örneklem t-testi kullanıldı. İstatistiksel anlamlılık $p<0,05$ olarak kabul edildi.

Correspondence: Mehmet Necmettin Mercimek MD, Samsun Liv Hospital, Department of Urology, Samsun, Turkiye Phone: +90 5435343964 E-mail: m.n.mercimek@hotmail.com ORCID-ID: orcid.org/0000-0002-0680-4451 Received: 28.12.2018 Accepted: 05.03.2019

Cite this article as: Mercimek MN, Bostancı Y, Özden E, Sarıkaya Ş. Protective Effects of Oral Sirolimus Therapy against ESWL-induced Kidney Tissue Damage in Rats. J Urol Surg 2019;6(3):190-195.

๑Copyright 2019 by the Association of Urological Surgery / Journal of Urological Surgery published by Galenos Publishing House. 
Bulgular: Ortalama histopatolojik skor, grup $1 \mathrm{E}$ ve $2 \mathrm{E}^{\prime}$ de $0,08 \pm 0,94$ ve $0,15 \pm 0,65$ ( $p=0,332$ ) idi. Grup $1 \mathrm{~L}^{\prime} \mathrm{de} 0,27 \pm 0,17$ ve grup $2 \mathrm{~L}$ 'de $0,05 \pm 0,06$ idi $(p<0,05)$. Grup 1E ve grup 1L karşılaştırıldığında, ortalama puan sırasıyla $0,08 \pm 0,94$ ve $0,27 \pm 0,17$ idi $(p<0,05)$. Ayrıca, grup $2 \mathrm{E}$ ve grup $2 \mathrm{~L}$ arasında ortalama histopatolojik skor açısından istatistiksel olarak anlamlı fark vardı. Ortalama puan sırasıyla $0,15 \pm 0,65 ' \mathrm{e} 0,05 \pm 0,06, p<0,05$ idi.

Sonuç: Şok dalga gücü ve frekansına bağlı olarak ESWL, kronik dönemde rat böbreklerinde önemli histopatolojik değişikliklere neden olabilir. Bu deneysel çalışmada, sirolimus tedavisinin ESWL'den sonra uzun dönem böbrek dokusu hasarında doku koruyucu bir etkiye sahip olabileceği düşünülmektedir.

Anahtar Kelimeler: Histopatolojik değişiklikler, Böbrek, ESWL, Sirolimus

\section{Introduction}

Extracorporeal shock wave lithotripsy (ESWL) is the treatment modality which uses shock waves (SWs) obtained from an external source to break a intra-corporeal stone into small pieces. Since its introduction in the 1980s, it has revolutionized the treatment of urinary stone disease. ESWL has rapidly gained worldwide acceptance because of its non-invasiveness, ease of use, high efficacy in the treatment of kidney and ureteral stones, and the variety of lithotripters (1). SWs carry out stone fragmentation via a number of dynamic and mechanic forces that are simply stated as cavitation and direct stress. It is known that cavitation is the primary mechanism of stone fragmentation. However, SWs that focus on the stone may cause injury to the thin-walled vessels as they pass through the tissues. Vascular injury may lead to bleeding and ischemic areas in the kidney and adjacent organs. At the end, the process in which cytokines and inflammatory cells take part in an active role begins. According to the degree of the vascular damage, fibrosis, scar formation and loss of the tissue function may occur (2).

The crucial cytokine responsible for fibrosis formation is transforming growth factor- $\beta$ (TGF- $\beta$ ). Many different processes, such as apoptosis, cell differentiation and growth, extracellular matrix (ECM) synthesis are regulated by TGF- $\beta$ (3). It has been determined by various clinical and experimental studies that sirolimus (rapamycin), an inhibitor of mammalian target of rapamycin (mTOR), has antifibrotic, antiproliferative and neovascularization inhibitory effects. It has been also shown that sirolimus prominently reduced TGF- $\beta$ expression and suppressed interstitial fibroblast activity, leading to a decrease in the production of ECM and fibrosis (4).

To our knowledge, the protective effects of sirolimus therapy against ESWL-induced kidney tissue damage have not been reported and remain largely unknown. In this study, we aimed to investigate the short- and long-term protective effects of oral sirolimus therapy ageinst ESWL-induced kidney tissue damage in an experimental rat model. The second aim of this study was to evaluate the damage in the renal parenchyma that occurred after acute changes related to ESWL.

\section{Material and Methods}

Twenty-four male Spraque-Dawley rats were used in the study. All rats were housed under standard conditions with a temperature-controlled environment and a 12-hour lightdark-cycle and with free access to food and water prior to and after the treatment protocol. All procedures were performed in compliance with the provision of the Strasbourg Universal Declaration on Animal Welfare of 1986 and this study was approved by Ondokuz Mayıs University local ethics committee on animal research (number: 2009/2).

The rats were randomly divided into 2 major experimental groups as ESWL (group 1) and ESWL + sirolimus (group 2). Subsequently, each group was divided into two subgroups as early (E) and late (L) periods. The groups are summarized in Table 1.

\section{Creating Experimental ESWL Model in Rats}

General anaesthesia was achieved by intraperitoneal administration of $100 \mathrm{mg} / \mathrm{kg}$ ketamine and $20 \mathrm{mg} / \mathrm{kg}$ xylazine hydrochloride (Rompun ${ }^{\circledR}$ ). A $24 \mathrm{G}$ intravenous catheter was inserted into the rats' tail vein. The rats were fixed on the wooden block and placed on ESWL table as the left lumbar region were open. The left renal collecting system was fluoroscopically visualized by administering sodium amidotrizoate (Urografin ${ }^{\circledR}$ $76 \%$ ) at a dose of $2 \mathrm{cc} / \mathrm{kg}$ via the intravenous catheter at the tail vein of the rats. Furthermore, the middle pole of the left kidney was focused on the F2 focal zone (Figure 1). After the focusing, a total of 1000 SWs were applied to the left kidney of all rats at $15 \mathrm{kV}, 60 \mathrm{SW} / \mathrm{min}$. The F2 focus was checked every 200 SWs. As a SWL generator, an Electrohydraulic Stonelith Smart Lithotripter (PCK, Turkiye) was used.

Table 1. Experimental rat model and number of rats per group

\begin{tabular}{lll}
\hline & $\begin{array}{l}\text { Group 1 } \\
\text { (ESWL) }\end{array}$ & $\begin{array}{l}\text { Group 2 } \\
\text { (ESWL + sirolimus) }\end{array}$ \\
\hline Early (E) & 6 & 6 \\
\hline Late (L) & 6 & 6 \\
\hline ESWL: Extracorporeal shock wave lithotripsy
\end{tabular}




\section{Group 1: ESWL}

After applying ESWL, the rats of the group $1 \mathrm{E}$ and group $1 \mathrm{~L}$ were sacrificed by exsanguination on the $15^{\text {th }}$ and $60^{\text {th }}$ days, respectively.

\section{Group 2: ESWL + sirolimus}

On the first-day post-ESWL, $0.8 \mathrm{mg} / \mathrm{kg}$ sirolimus was given orally by gastric lavage to the rats of group $2 \mathrm{E}$ and group $2 \mathrm{~L}$ (5). Left nephrectomy was performed on day 15 in group $2 \mathrm{E}$ and on day 60 in group $2 \mathrm{~L}$.

\section{Histopathologic Evaluation}

The extracted left kidneys were macroscopically evaluated for subcapsular haemorrhage on the anterior and posterior sides. Then, they were kept in 10\% formaldehyde for 24 hours. Tissue follow-up procedures were followed to prepare 4-micron paraffin-embedded sections. The sections were stained with haematoxylin-eosin (H\&E) and periodic acid-schiff. Pathological preparations were evaluated using light microscopy (Olympus BX50, Olympus CO, Japan) by a single pathologist who was blind to the study groups. Tubular damage (tubular dilatation, intratubular bleeding), interstitial inflammation, interstitial haemorrhage, glomerular and vascular congestion in the renal cortex were all examined at a magnification of 200 under a light microscope. In addition, for chronic changes, the presence of tubular atrophy and interstitial fibrosis was also assessed. Modified from the study of Li et al. (6), the prevalence of damage findings was scored on a scale of 0-4 with a semi quantitatively expressed percentile (Table 2). In the present study, tubular

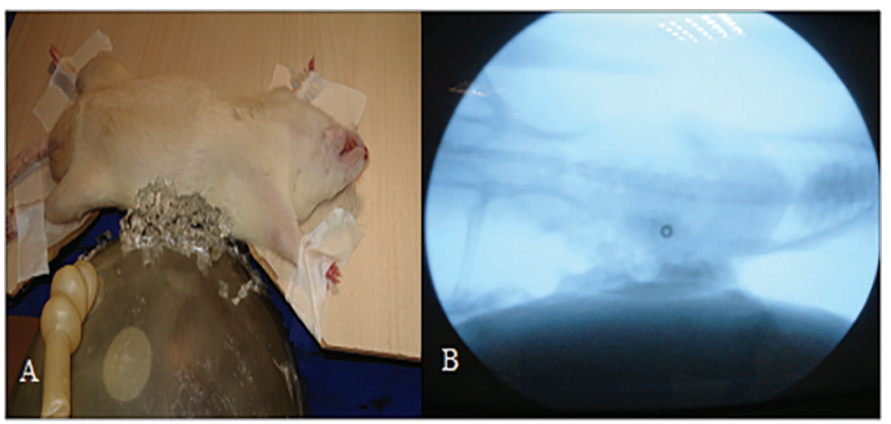

Figure 1. A) Fixation of the rat on wooden blocks; B) F2 focus; after administration of contrast medium

Table 2. Histopathological scoring system

\begin{tabular}{ll}
\hline Score & Percent \\
\hline 0 & None \\
\hline 1 & $<10 \%$ \\
\hline 2 & $10-25 \%$ \\
\hline 3 & $26-75 \%$ \\
\hline 4 & $>75 \%$ \\
\hline $\begin{array}{l}\text { Scoring system that expresses the prevalence of histopathological findings in percent } \\
\text { area }\end{array}$
\end{tabular}

injury, interstitial changes, as well as scar formation, were scored semi quantitatively for at least 10 cortical fields in each sample. Average score was calculated for each subject.

\section{Statistical Analysis}

Statistical Package of Social Sciences 15 (SPSS 15, Chicago, IL, USA) was used for statistical analysis. Independent samples t-test was used to compare the groups. The statistical significance was accepted as $p<0.05$.

\section{Results}

No subcapsular or intraparenchymal haemorrhage was found on macroscopic examination in any of the subjects. When histopathological evaluation scores were compared between the groups, the mean score was $0.08 \pm 0.94$ and $0.15 \pm 0.65$ in group $1 \mathrm{E}$ and $2 \mathrm{E}$, respectively $(\mathrm{p}=0.332)$. The mean score was $0.27 \pm 0.17$ in group $1 \mathrm{~L}$ and $0.05 \pm 0.06$ in group $2 \mathrm{~L},(\mathrm{p}<0.05)$ (Figure $2 \mathrm{~A}$ and $2 \mathrm{~B})$. When group $1 \mathrm{E}$ and group $1 \mathrm{~L}$ were compared, the mean

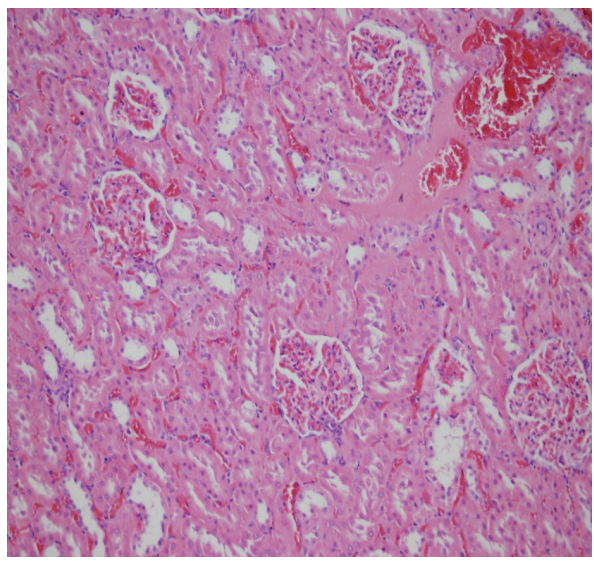

Figure 2A. Group 1L, sample no: 3: H\&E x200: Rat with a histopathologic score of 2

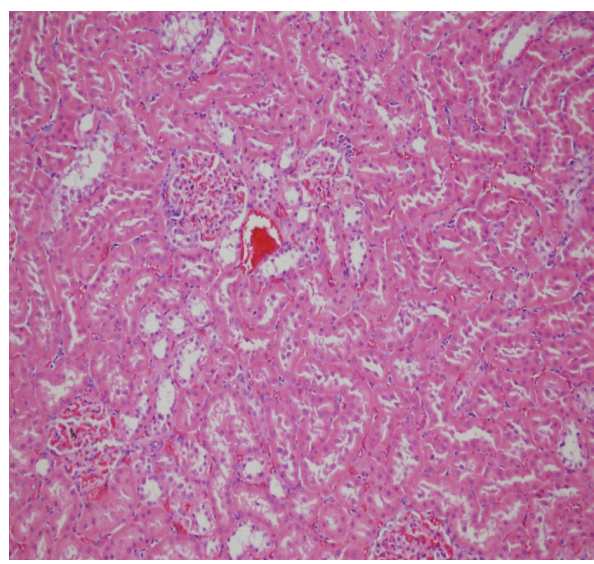

Figure 2B: Group 2L, sample no: 4: H\&E x200: Rat with a histopathologic score of 1 ; Note that interstitial edema is evident. Although edema was a sign of the acute period in histopathologic evaluation in general, it was found in the chronic period rats as a side effect of sirolimus 
score was found to be $0.08 \pm 0.94$ and $0.27 \pm 0.17$, respectively $(p<0.05)$. Furthermore, a statistically difference was found in mean histopathological score between group $2 \mathrm{E}$ and group $2 \mathrm{~L}$. The mean score was $0.15 \pm 0.65$ vs $0.05 \pm 0.06, p<0.05$ (Figure 3 ).

When the changes in body weights were examined before and after the study in group 1, the mean body weight in the rats of group $1 \mathrm{E}$ and group $1 \mathrm{~L}$ was $291.5 \pm 6.18 \mathrm{~g}$ vs $292 \pm 5.76 \mathrm{~g}$ and $295.1 \pm 7.25 \mathrm{~g}$ vs $294.8 \pm 6.64 \mathrm{~g}$, respectively. The change in body weight in both subgroups of group 1 was not statistically significant ( $p=0.203$ and $p=0.638$, respectively). Nevertheless, in group 2, the mean body weight in the rats of group $2 \mathrm{E}$ and group $2 \mathrm{~L}$ was $294 \pm 5.54$ vs $282 \pm 5.32 \mathrm{~g}$ and $297.5 \pm 2.58$ vs $273.1 \pm 3.76$ $g$, respectively. The change in body weight in both subgroups was statistically significant ( $p=0.001$ and $p=0.006$, respectively).

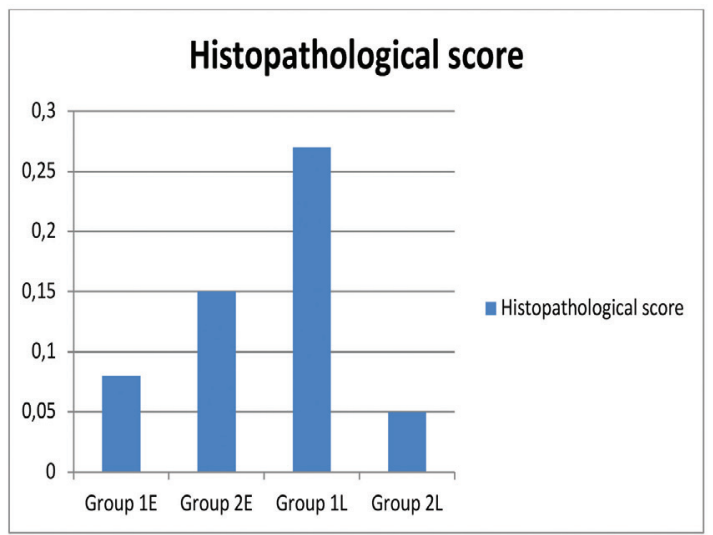

Figure 3. The mean histopathological score of each group

\section{Discussion}

ESWL is the only non-invasive treatment modality for the management of stones located in the upper urinary system. The overall risk of side-effect is lower in ESWL compared to other minimally-invasive treatment options such as ureterorenoscopy retrograde intrarenal surgery, and percutaneous nephrolithotomy (7). Short-term complications of ESWL include perirenal and/ or intraparenchymal haemorrhage or hematoma, infectious complications, and adverse events associated with residual stone fragments (8). Furthermore, long-term adverse effects of ESWL on the kidney, which are still a matter of debate, are loss of parenchyma in the functioning kidney that might be related with chronic kidney disease (CKD) and arterial hypertension. Nonetheless, it has been stated in a systematic review that there was no evidence supporting an association between ESWL and long-term adverse effects (8).

Hazardous effects of SWs on blood vessels and renal tubules have been demonstrated in animal studies $(6,9)$. Vascular damage might result in haematuria or hematoma formation as well. However, this tissue damage usually occurs in the field where the focal zone is targeted (1).

In addition, it is asserted that hematuria occurs in all patients who undergo SWL treatment after receiving around 200 SWs. In another human study comparing electromagnetic versus electrohydraulic lithotriptors, it has been reported that electromagnetic lithotriptor caused higher number of red blood cells in the urine compared to electrohydraulic lithotriptor in the early post-SWL period. However, cytologic evaluations performed 10 days after SWL therapy showed recovery of all abnormal cytologic findings (10). On the other hand, an intraparenchymal, subcapsular and perirenal hematoma is another well-known ESWL-induced acute renal complication. The incidence of hematoma detected on ultrasound examination has been reported to be $1 \%$. However, it has been reported that the incidence of hematoma would have increased to 30\% when the radiological evaluation was performed by computed tomography or magnetic resonance imaging (MRI). It has also been declared that the frequency of hematoma differs according to the radiological method, time of evaluation as well as lithotripter type (11). Age of the patient, history of hypertension, bleeding diathesis, antiplatelet drug use, body mass index, stone size, diabetes mellitus, frequency and strength of shock wave, and duration of treatment are predisposing risk factors for hematoma formation $(11,12,13)$.

It has been stated in a prospective clinical study that lower energy SW decreases the incidence of renal hematoma detected by MRI. Moreover, it has been reported that a low energy setting caused smaller diameter hematomas and that these hematomas disappeared within 1 week (11). Another study also reported that most of SWL-related renal hematomas resolved within weeks without long-term adverse effects (14). The abovementioned acute complications have been shown in many experimental and animal studies in the literature. Furthermore, in many studies, acute histopathological changes after ESWL were evaluated immediately after ESWL or within a few weeks $(13,15)$. It is well known that ESWL may cause vascular injury as an acute side effect on kidney parenchyma. Vascular injury and hematoma might initiate an inflammatory response that ends up with scar formation. Morris et al. (16) have shown that dose-dependent scar volume increased 10 -fold in rabbits when the number of SWs applied to the kidney was increased from 1000 to 2000 pulses. However, the clinical reflection of chronic scar formation has not been fully clarified for many years. In our study, in the beginning, we planned to apply a total of 2000 SWs but it was reduced to 1000 SWs due to the death of rats during or immediately after the experiment.

It has been reported in a study on pigs that a dose of 2000 SWs using a Dornier HM3 lithotripter operated at $24 \mathrm{kV}$ and SWs 
applied at $120 \mathrm{SW} /$ min produced a parenchymal lesion measuring thereabouts $5 \%$ to $6 \%$ of a functional renal volume (17). In the present study, the first histopathological examinations were made on the $2^{\text {nd }}$ week after ESWL to evaluate the damage that may occur after acute changes in the renal parenchyma. The mean area affected by ESWL in both $\mathrm{E}$ groups was less than $15 \%$. Furthermore, there was no subcapsular hematoma detected in both groups. In our opinion, the reduction in total SWs, frequency, and power was associated with the results in E groups. Since intraparenchymal or subcapsular haemorrhage and tubular damage detected in the E period after ESWL are expected to decrease in the second week, the time of examination of the subjects may also be another factor.

To date, there are no studies showing long-term effects of ESWL on the kidney in detail. In experimental studies, only dosedependent renal fibrosis formation has been demonstrated in dogs and rabbits by different researchers. However, it is still unclear how to prevent SWL-associated kidney tissue damage in clinical practice.

The formation of fibrosis after acute tissue damage is formed over various mediators. In experimental studies, the upregulation of TGF- $\beta$ and vascular endothelial growth factor has been proven as a crucial step of the initiation of the process that results in fibrosis. TGF- $\beta$ also regulates many different biological activities such as cell growth, apoptosis, cell differentiation, and ECM synthesis (18). Sirolimus, an inhibitor of mTOR, has anti-inflammatory and anti-fibrotic effects (19). In in vivo studies, it was shown that sirolimus significantly decreased TGF- $\beta$ expression and suppressed interstitial fibroblast activity and decreased ECM production and fibrosis (4). The main purpose of our study was to investigate the effect of ESWL on histopathological changes in kidney tissue due to the antifibrotic properties of sirolimus, an inhibitor of mTOR. For this reason, two main groups were formed and these groups were divided into two subgroups: $E$ and $L$ period. A control group and sham group were not included.

According to the literature, orally administered low-dose sirolimus ( $\geq 0.5 \mathrm{mg} / \mathrm{kg} / \mathrm{day}$ ) had anti-fibroblastic, antiproliferative and neovascularization effects. Stepkowski (5) estimated oral bioavailability of sirolimus at $10 \%$. When the intravenous dose of $0.08 \mathrm{mg} / \mathrm{kg} /$ day was compared with an oral dose of $0.8 \mathrm{mg} /$ $\mathrm{kg} / \mathrm{day}$, it was found that the average survival time of heart allografts was similar. In our study, we prepared the dose to be given to rats the based on this study (5).

In this study, it was determined that sirolimus decreased histopathological changes in the kidney related to ESWL in long term. However, the effect of sirolimus on histopathological changes in the first two weeks could not be determined.
In another study in which the effect of sirolimus on body weight was evaluated, a significant weight loss was detected after 12 weeks in group administered sirolimus $1.0 \mathrm{mg} / \mathrm{kg} 3$ times a week (20). In our study, the rats were treated with oral sirolimus at a dose of $0.8 \mathrm{mg} / \mathrm{kg} /$ day. A statistically significant decrease in body weight was determined in both the $E$ groups $(p<0.05)$ and in the $L$ period groups $(p<0.05)$.The detection of a statistically significant weight loss among long-term groups was a side effect of sirolimus (20).

In a retrospective study evaluating the effect of ESWL on renal functions in 131 patients with CKD and kidney stones, stone therapy with ESWL delayed the deterioration in renal function in patients with CKD. In patients with chronic renal failure; if there were kidney stones and not treated, annual deterioration in renal function was more common than those treated with ESWL. As a result, it was stated that ESWL could be recommended in patients with CKD and kidney stone (21). Sirolimus provides appropriate immunosuppression without nephrotoxicity, unlike calcineurin inhibitors. It could be used as an alternative drug in a patient with CKD who has organ transplantation (22).

\section{Study Limitations}

Several limitations of our study should be noted. First, TGF- $\beta$ molecule, which is an important marker for the determination of fibrosis, could not be managed at the tissue level due to technical deficiencies. Therefore, evaluations could only be made at the histopathological level. Second, our rat model of ESWL-induced kidney tissue damage is not entirely analogous to clinical conditions seen in patients.

\section{Conclusion}

Based on this study, we think that sirolimus may be beneficial in protecting the existing renal functions and in decreasing tissue damage in kidney tissue after ESWL especially in patients with CKD. However, further investigations are needed to confirm or support this theory.

\section{Ethics}

Ethics Committee Approval: This study was approved by Ondokuz Mayıs University local ethical committee on animal research (number: 2009/2).

Informed Consent: All procedures were performed in compliance with the provision of the Strasbourg Universal Declaration on Animal Welfare of 1986.

Peer-review: Externally peer-reviewed.

\section{Authorship Contributions}

Concept: M.N.M., Ş.S, E.Ö., Design: M.N.M, E.Ö., Y.B., Data Collection and/or Processing: M.N.M., Y.B., Analysis and/or 
Interpretation: E.Ö., Y.B., M.N.M., Literature Research: M.N.M., Writing: M.N.M., S..S.

\section{Conflict of Interest: No conflict of interest was declared by the} authors.

Financial Disclosure: This study was funded by Ondokuz Mayis University project management office.

\section{References}

1. Skolarikos A, Alivizatos $G$, de la Rosette J. Extracorporeal shock wave lithotripsy 25 years later: complications and their prevention. european urology 2006;50:981-990.

2. McAteer JA, Evan AP. The acute and long-term adverse effects of shock wave lithotripsy. Seminars in nephrology. Vol 28: Elsevier; 2008:200-213.

3. Wang Q, Usinger W, Nichols B, Gray J, Xu L, Seeley TW, Brenner M, Guo G, Zhang $W$, Oliver $N$. Cooperative interaction of CTGF and TGF- $\beta$ in animal models of fibrotic disease. Fibrogenesis \& tissue repair 2011;4:4.

4. Wang $S$, Wilkes MC, Leof EB, Hirschberg R. Noncanonical TGF- $\beta$ p pathways, mTORC1 and Abl, in renal interstitial fibrogenesis. American Journal of Physiology-Renal Physiology 2009;298:F142-F149.

5. Stepkowski S. Preclinical results of sirolimus treatment in transplant models. Transplantation proceedings. Elsevier; 2003:219-226.

6. Li X, He D, Zhang L, Cheng X, Sheng B, Luo Y. A novel antioxidant agent, astragalosides, prevents shock wave-induced renal oxidative injury in rabbits. Urological research 2006;34:277-282.

7. Mateu PB, Alba AB, Liatsikos E, Villa MT, López-Acón J, de Guzmán Ordaz $D$, Tormo FB. Is extracorporeal shock wave lithotripsy a current treatment for urolithiasis? A systematic review. Actas Urológicas Españolas (English Edition) 2017;41:426-434.

8. Fankhauser CD, Kranzbuehler B, Poyet C, Hermanns T, Sulser T, Steurer J. Long-term adverse effects of extracorporeal shock-wave lithotripsy for nephrolithiasis and ureterolithiasis: a systematic review. Urology 2015;85:991-1006.

9. Newman R, Hackett R, Senior D, Brock K, Feldman J, Sosnowski J, Finlayson B. Pathologic effects of ESWL on canine renal tissue. Urology 1987;29:194200.

10. Mustafa $M$, Aburas $H$, Helo FM, Qarawi L. Electromagnetic and electrohydraulic shock wave lithotripsy-induced urothelial damage: is there a difference? Journal of endourology 2017;31:180-184.
11. Sheir KZ, El-Ghar MA, Elshal AM, Elsaadany MM, Taha D-E, El-Nahas AR. Evaluation of acute post-shock wave lithotripsy renal changes by dynamic magnetic resonance imaging: a prospective clinical study. The Journal of urology 2014;192:1705-1709.

12. Li K, Lin T, Zhang C, Fan X, Xu K, Bi L, Han J, Huang H, Liu H, Dong W. Optimal frequency of shock wave lithotripsy in urolithiasis treatment: a systematic review and meta-analysis of randomized controlled trials. The Journal of urology 2013;190:1260-1267.

13. Dhar NB, Thornton J, Karafa MT, Streem SB. A multivariate analysis of risk factors associated with subcapsular hematoma formation following electromagnetic shock wave lithotripsy. The Journal of urology 2004;172:2271-2274.

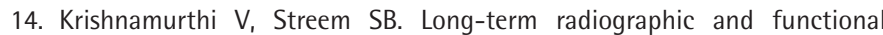
outcome of extracorporeal shock wave lithotripsy induced perirenal hematomas. The Journal of urology 1995;154:1673-1675.

15. Kang DH, Cho KS, Ham WS, Lee H, Kwon JK, Choi YD, Lee JY. Comparison of high, intermediate, and low frequency shock wave lithotripsy for urinary tract stone disease: systematic review and network meta-analysis. PLoS One 2016;11:e0158661.

16. Morris JS, Husmann DA, Wilson WT, Preminger GM. Temporal effects of shock wave lithotripsy. The Journal of urology 1991;145:881-883.

17. Willis LR, Evan AP, Connors BA, Handa RK, Blomgren PM, Lingeman JE Prevention of lithotripsy-induced renal injury by pretreating kidneys with low-energy shock waves. Journal of the American Society of Nephrology 2006;17:663-673.

18. Ghadimi M, Dashti-Khavidaki S, Khalili H. mTOR inhibitors for management of encapsulating peritoneal sclerosis: a review of literatures. Renal failure 2016;38:1574-1580

19. Tulek B, Kiyan E, Toy H, Kiyici A, Narin C, Suerdem M. Anti-inflammatory and anti-fibrotic effects of sirolimus on bleomycin-induced pulmonary fibrosis in rats. Clinical and Investigative Medicine 2011:E341-E348.

20. Hebert $M$, Licursi $M$, Jensen B, Baker A, Milway $S$, Malsbury $C$, Grant VL, Adamec $R$, Hirasawa M, Blundell J. Single rapamycin administration induces prolonged downward shift in defended body weight in rats. PloS one 2014;9:e93691.

21. Yoo DE, Han SH, Oh HJ, Kim SJ, Shin DH, Lee MJ, Yoo T-H, Kang S-W, Choi $\mathrm{KH}$. Removal of kidney stones by extracorporeal shock wave lithotripsy is associated with delayed progression of chronic kidney disease. Yonsei medical journal 2012;53:708-714.

22. Moloney E, O'Mahony U, Kirwan M, McCarthy J, Hurley J, Wood A, Egan J. Pharmacokinetics of sirolimus in heart transplant recipients with chronic renal impairment. Transplantation proceedings. Vol 36: Elsevier; 2004:1547-1550. 